\title{
Petrology, geochemistry, and tectonic setting of some Carboniferous plutons of the eastern Cobequid Hills
}

\author{
G. Pe-Piper \\ Department of Geology, St. Mary's University, Halifax, Nova Scotia B3H 3C3, Canada \\ J.B. Murphy \\ Department of Geology, St. Francis Xavier University \\ Antigonish, Nova Scotia B2G 1CO, Canada
}

and

\author{
D.S. Turner \\ Department of Geology, St. Mary's University, Halifax, Nova Scotia B3H 3C3, Canada
}

Date Received May 25, 1988

Date Accepted May 1, 1989

\begin{abstract}
The Early Carboniferous Pleasant Hills and Hart Lake - Byers Lake granitoid plutons are the youngest plutons in the eastern Cobequid Highlands. In both plutons, coarse-grained granites predominate, but both also include fine-grained phases, most common at their margins. Modally, these granites fall in the "alkali-feldspar granite" field of the IUGS classification. Geochemically, both alkaline and subalkaline granites are present. The granites have relatively low concentrations of $\mathrm{Al}_{2} \mathrm{O}_{3}$ and $\mathrm{CaO}$, high alkali content, and molar $\left(\mathrm{Na}_{2} \mathrm{O}+\mathrm{K}_{2} \mathrm{O}\right) / \mathrm{Al}_{2} \mathrm{O}_{3}$ in the range 0.84 to 0.99 . The granites have within-plate trace element characteristics and are more alkaline and less aluminous than similar Early Carboniferous within-plate granites in the westem Cobequid Highlands. This entire suite of Early Carboniferous granites in the Cobequid Highlands is approximately synchronous with extrusion of the Fountain Lake Group volcanic rocks. This igneous activity is apparently related to local extension along the Cobequid and other major strike-slip faults.
\end{abstract}

Les plutons granitoïdes éocarboniferes de Pleasant Hills et de Hart Lake - Byers Lake sont les plus jeunes plutons de l'est des Monts Cobequid. Les granites à grain grossier prédominent au sein de l'un et l'autre pluton quoiqu'on y retrouve aussi des phases à grain fin, les plus souvent près des marges. En termes de mode, ces granites tombent dans le domaine des "granites à feldspath alcalin" de la classification IUGS. Du point de vue de la géochimie, les granites sont aussi bien alcalins que subalcalins. Leurs concentrations en $\mathrm{Al}_{2} \mathrm{O}_{3}$ et $\mathrm{CaO}$ sont relativement basses, leurs teneurs en alcali hautes et leurs rapports molaires $\left(\mathrm{Na}_{2} \mathrm{O}+\mathrm{K}_{2} \mathrm{O}\right) / \mathrm{Al}_{2} \mathrm{O}_{3}$ vont de 0.84 à 0.99 . Les granites renferment des éléments en traces à caractère intraplaque; ils sont plus alcalins et moins alumineux que leurs homologues de l'ouest des Monts Cobequid. Ce cortège entier de granites éocarboniferes dans les Monts Cobequid est approximativement synchrone de l'extrusion des volcanites du Groupe de Fountain Lake. Cette activité ignée semble liée à une extension locale le long de la Faille de Cobequid et d'autres décrochements majeurs.

[Traduit par le journal]

\section{INTRODUCTION}

Carboniferous granitoid rocks are voluminous in the eastern Cobequid Highlands (Fig. 1) in the Avalon Terrane of northern Nova Scotia (Donohoe and Wallace, 1982, 1985). They occur in five plutons: the Pleasant Hills, Gilbert Mountain, Hart Lake Byers Lake, Debert River and Salmon River plutons (Fig. 2). These plutons comprise distinctive red to pink granites. Whole rock Rb-Sr isochron dating yielded a date of $315 \pm 25 \mathrm{Ma}$ for the Pleasant Hills pluton (Cormier, 1979) and $348 \pm 5 \mathrm{Ma}$ for the Hart Lake - Byers Lake pluton (Donohoe et al., 1986).
Geographically associated with the Early Carboniferous granite plutons is a large, complex, predominantly gabbroic pluton, the Folly Lake pluton, and several smaller gabbro or diorite bodies. These mafic plutons have not been radiometrically dated. The Folly Lake pluton intrudes folded Early Devonian strata and is intruded by granites at the margin of the Hart Lake - Byers Lake pluton; it is therefore regarded as DevonoCarboniferous in age (Donohoe and Wallace, 1982). This pluton contains some minor granite phases, locally making up 10-30\% of the rock. Many of these granite-gabbro contacts are embayed, with chilling of gabbro against the granite. These textures 


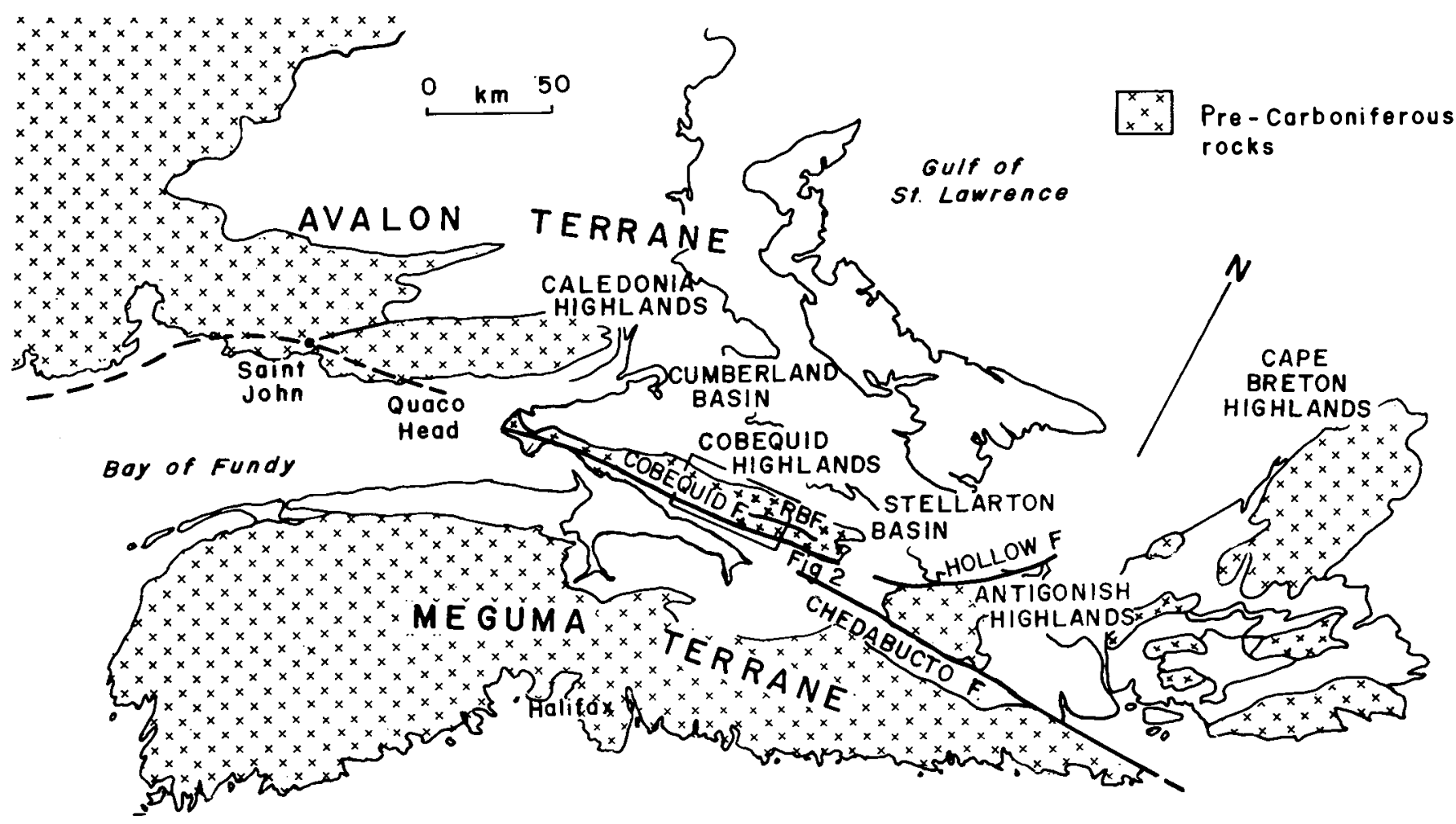

Fig. 1. Map showing tectonic setting of study area in the eastern Cobequid Highlands.

suggest to us synchronous cooling of granitic and gabbroic magmas.

Early Carboniferous granite plutons, with only minor gabbroic phases, also occur in the western Cobequid Highlands. In this area, the granites appear to be high-level plutons associated with the extrusion of rhyolite and minor basalt of the Fountain Lake Group, which yields similar radiometric ages (Pe-Piper $e t$ al., submitted).

The evolution of Devono-Carboniferous rocks of the A valon Terrane of Nova Scotia was strongly influenced by motion on major ENE- and E-trending faults associated with emplacement of the Meguma Terrane (Donohoe and Wallace, 1985; Keppie and Dallmeyer, 1987). This resulted in penecontemporaneous development of pull-apart basins, thrusts, uplifts and depressions that strongly influenced sedimentation (Ryan et al., 1987). In this paper, we point out the relationship between this tectonic setting and the magmatism.

To date none of the plutons in the eastern Cobequid Highlands has been described in detail and little is known of their magmatic affinity or tectonic setting. Work on the petrogenesis of these plutons, and their relationship to their regional tectonic setting in in progress. In this paper we present preliminary information on the petrology and geochemistry of the Pleasant Hills and Hart Lake - Byers Lake plutons (Fig. 2). A more complete study of all the Devono-Carboniferous plutonism will be published at a later date when field and analytical work is completed.

\section{FIELD RELATIONSHIPS}

The Pleasant Hills pluton (Fig. 2) is a $17 \mathrm{~km}$ long composite granitic pluton that is located along the general trend of the Rockland Brook fault (Donohoe and Wallace, 1988), and locally is deformed by the fault. Three phases are distinguished: coarsegrained granite (locally with rapakivi texture); fine-grained granite; and porphyry. These appear to form a number of discrete intrusive bodies. The coarse granite locally contains xenoliths of flow-banded rhyolite. The pluton is truncated on its southern margin by the Cobequid Fault.

The $30 \mathrm{~km}$ long Hart Lake - Byers Lake pluton (Fig. 2) lies on the northern margin of the Folly Lake gabbroic pluton. The northwestern edge of the pluton is onlapped by the Westphalian A Boss Point Formation. The southeastern part of the pluton is cut by the Rockland Brook Fault, producing a ductile shear zone. The northern and eastern margin of the pluton cross cuts DevonoCarboniferous volcanic rocks of the Byers Brook Formation (Fountain Lake Group), and although outcrop is insufficient to demonstrate specific intrusive contacts, the presence of a finegrained marginal phase of the pluton that is hundreds of metres wide suggests an intrusive relationship. A similar fine-grained margin occurs where the granite is in contact with the Folly Lake pluton, and granitic dykes appear to cut the gabbroic pluton. In both areas, the fine-grained marginal phase consists of porphyritic or equigranular granophyric granite. 


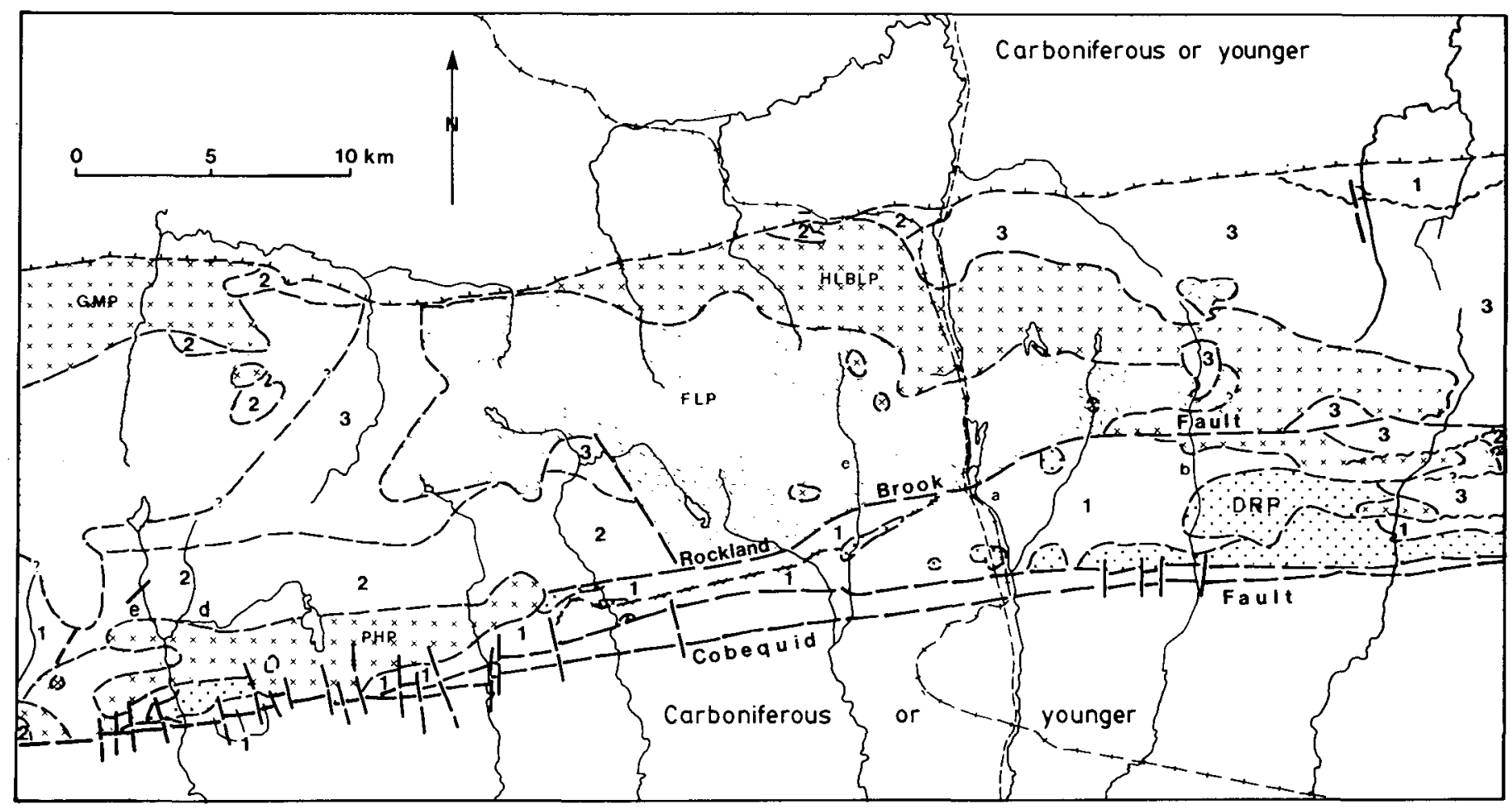

Nonplutonic rocks

Plutonic rocks:

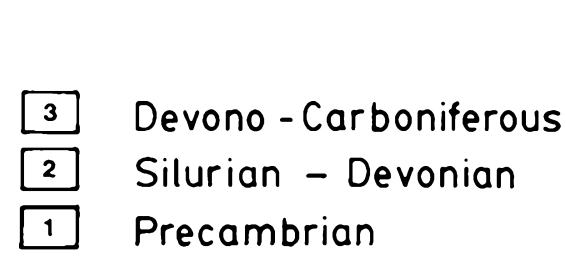

$\left[\begin{array}{l}x \times \\ x x]\end{array}\right]$ Carboniferous

Devono-Carboniferous

Precambrian

Fig. 2. Geological map of the Pleasant Hills and the Hart Lake - Byers Lake plutons and surrounding area. PHP - Pleasant Hills pluton; HLBL - Hart Lake - Byers Lake pluton; GMP - Gilbert Mountain pluton; DRP - Debert River pluton; FRP - Folly Lake pluton. (a) Folly River; (b) Debert River; (c) Rockland Brook; (d) Chain Lake Brook; (e) West Economy River. The Salmon River pluton is about $10 \mathrm{~km}$ east of the Debert River pluton.

The dominant phase in the main part of the Hart Lake - Byers Lake pluton is coarse-grained granite, rich in alkali-feldspar and quartz. This granite is cut by late pegmatitic veins, many of which are mineralized (especially in the Folly River-Debert River area) with magnetite, chalcopyrite, pyrite, tourmaline and (?)siderite.

Within the Hart Lake - Byers Lake pluton, between the Folly and Debert Rivers (in the general area mapped as "Cgaf" by Donohoe and Wallace, 1982), there is an inlier of Folly River gabbro that is cut by coarse leucocratic granite with chilled margins. Associated granite-pegmatite is mineralised with magnetite, chalcopyrite, pyrite and siderite. In this same area, xenoliths of flow-banded rhyolite occur.

\section{PETROGRAPHY}

\section{Pleasant Hills Pluton}

Only the fine-grained granite phase has been studied in detail from the Pleasant Hills pluton (Table 1). It consists of equigranu- lar (Plate 1A), fine-grained granite, with micromyrmekitic, micrographic or granitic textures. Locally, porphyritic granite is found (Plate 1B). It is alkali-feldspar granite displaying perthitic intergrowths of albite and K-feldspar. Both quartz and albite may be embayed. Clusters of very fine-grained magnetite crystals are randomly dispersed throughout the rock. Minor subhedral pyrite is altered to hematite. Biotite is olive green, except for rare brown crystals, occuring in fine-grained crystal clusters. Accessory sphene and zircon are associated with ferromagnesian mineral clusters. Rutile and fluorite are also present. Muscovite is a pervasive alteration product; some biotite is altered to chlorite.

\section{Hart Lake - Byers Lake Pluton}

(a) The fine-grained marginal phase of the Hart Lake - Byers Lake pluton is alkali-feldspar granite (Table 1). It is generally equigranular, with granitic or graphic texture (Plate 1C). Microphenocrysts of perthite or quartz occur in some samples. Kfeldspar occurs in perthitic and graphic intergrowths with albite 
Table 1. Modal compositions (\%) of the Pleasant Hills and Hart Lake - Byers Lake plutons

\begin{tabular}{|c|c|c|c|c|c|c|c|c|c|c|c|c|c|}
\hline \multirow[b]{2}{*}{ Sample } & \multirow[b]{2}{*}{$25-5-1$} & \multicolumn{3}{|c|}{ Pleasant Hills Pluton } & \multirow[b]{2}{*}{$26-13-2$} & \multicolumn{5}{|c|}{$\begin{array}{l}\text { Hart Lake-Byers Lake Pluton } \\
\text { Marginal granites } \quad \text { Coarse granites }\end{array}$} & \multicolumn{3}{|c|}{ Leucocratic granite } \\
\hline & & $25-5-6$ & $25-5-8$ & $26-13-1$ & & $35-5-1$ & $35-5-2$ & $29-8-7$ & $35-7-1$ & $36-7-1$ & $36-5-1$ & $36-6-2$ & $44-1-1$ \\
\hline Plagioclase & - & - & - & - & $3.1^{2}$ & $1.8^{2}$ & - & - & - & - & - & - & - \\
\hline Albite 3 & 20.8 & 22.6 & 12.7 & 27.7 & 26.0 & 20.9 & 26.7 & 30.1 & $23.6^{4}$ & 28.1 & $22.2^{4}$ & 18.5 & 28.6 \\
\hline Quartz & $25 \cdot 3$ & 24.6 & 32.2 & 25.3 & 26.5 & 32.2 & 24.8 & 35.0 & 46.8 & 29.4 & $31 \cdot 3$ & 43.1 & 33.1 \\
\hline K-feldspar & 52.4 & 50.7 & 52.9 & 41.7 & 43.4 & 39.5 & 43.0 & 31.6 & 23.7 & 40.2 & 44.5 & 37.4 & 36.2 \\
\hline Hornblende & - & - & - & - & - & 2.2 & 1.6 & 0.6 & 0.6 & - & 0.3 & - & - \\
\hline Biotite & - & - & - & - & 0.5 & 0.3 & - & 0.2 & - & 1.0 & 0.3 & - & 0.5 \\
\hline Opaques & 1.5 & 2.1 & 2.1 & 4.8 & 3.2 & 0.4 & 1.1 & 0.7 & 0.8 & 0.5 & 1.5 & 0.8 & 0.8 \\
\hline Chlorite & - & - & - & - & - & 1.0 & 0.6 & 1.7 & - & 0.9 & - & - & - \\
\hline Epidote & - & - & - & 0.3 & 0.3 & 0.1 & 0.2 & - & - & - & - & 0.2 & - \\
\hline Zircon & - & - & - & 0.3 & - & - & 0.2 & - & - & - & - & - & - \\
\hline $\begin{array}{l}\text { Red alt.min. } \\
\text { Unknown }\end{array}$ & - & $\cdot-$ & - & - & - & 0.3 & - & 0.1 & 1.0 & - & - & - & 0.2 \\
\hline Fluorite & - & - & - & - & - & - & - & - & 0.1 & - & - & - & - \\
\hline Arfvedsonite & - & - & - & - & - & - & - & - & 3.5 & - & - & - & 0.6 \\
\hline Total & 100.0 & 100.0 & 99.9 & 100.1 & 99.9 & 100.0 & 100.0 & 100.0 & 100.1 & 100.1 & 100.1 & 100.0 & 100.0 \\
\hline $\begin{array}{l}\text { Color index } \\
\text { IUGS } Q-P-A\end{array}$ & $\begin{array}{c}1.5 \\
\text { normalized }\end{array}$ & $\begin{array}{c}2.1 \\
\text { to } 100)\end{array}$ & 2.1 & 5.3 & 4.0 & $4 \cdot 3$ & 3.7 & 3.2 & 6.0 & 2.3 & 2.0 & 1.0 & 1.9 \\
\hline Plagioclase & - & - & - & - & - & 3.2 & 1.9 & - & - & - & - & - & - \\
\hline $\begin{array}{l}\text { Quartz } \\
\text { Alkali- }\end{array}$ & 25.7 & 25.1 & 32.9 & 26.7 & 27.6 & 33.6 & 25.8 & 36.2 & 49.7 & 30.1 & 31.9 & 43.6 & 33.8 \\
\hline feldspar 1 & 74.3 & 74.9 & 67.1 & 73.3 & 45.2 & 63.1 & 72.3 & 63.8 & 50.3 & 60.9 & 68.1 & 56.4 & 66.2 \\
\hline Name & $\mathrm{AFG}$ & AFG & $\mathrm{AFG}$ & $\mathrm{AFG}$ & $\mathrm{AFG}$ & $\mathrm{AFG}$ & $A F G$ & $\mathrm{AFG}$ & $\mathrm{AFG}$ & $\mathrm{AFG}$ & $A F G$ & $\mathrm{AFG}$ & $\mathrm{AFG}$ \\
\hline
\end{tabular}

\section{Notes: AFG: Alkali-feldspar granite}
1. Albite is counted as alkali-feldspar in IUGS Calculations
2. Plagioclase refers to individual plagioclase grains of which composition in unknown
3. Plagioclase in perthite structure and as individual crystals
4. Feldspars analysed by electron microprobe 
and quartz respectively. Albite also rarely occurs as individual grains with pericline twinning. Quartz is always anhedral, some occurring in crystal clusters or cuniform-shaped grains intergrown with orthoclase or perthite. Ferromagnesian minerals occur in clusters. Fresh samples have minor green hornblende and deep brown biotite while in more altered samples homblende and some biotite has altered to chlorite. Rarely, the amphibole present is grey to deep blue arfvedsonite. Many feldspars are altered to epidote or clay minerals. Bright orange allanite in some cases appears to pseudomorph amphibole cross sections and in other cases is overgrown on hornblende or arfvedsonite.

(b) The main phase of the Hart Lake - Byers Lake pluton is a coarse, equigranular, pink, leucocratic alkali-feldspar granite, showing granitic to graphic texture. Feldspars occur in perthitic intergrowths of orthoclase and albite, except for rare discrete subhedral albite laths. Quartz occurs in large polycrystalline masses which sometimes have cuniform outline. The individual grains are fairly coarse, anhedral and show strain in the form of undulose extinction and subgrain boundaries. Ferromagnesian minerals are in low abundance and generally occur in polymineralic clusters. Biotite is present as ragged brownish to greenish grains, many of which are altered to chlorite (penninite). Amphibole is present as subhedral to anhedral grains, most commonly olive green hornblende, rarely blue to grey arfvedsonite. Many opaques occur as polycrystalline patches of ilmenite associated with amphibole. Crystals of magnetite with hematite rims occur commonly as inclusions in feldspars. Magnetite occurs also as inclusions in arfvedsonite and commonly shows exsolution of ilmenite and hematite. Accessory minerals include common zircon (subhedral inclusions in chlorite, hornblende or opaques, or as isolated grains) and rare sphene and fluorite. Some feldspars are altered to epidote. In the vicinity of the ferromagnesian mineral clusters, feldspars are stained reddish-brown; amphibole is partly altered to yellow-brown allanite.

(c) The leucocratic granite which intrudes the inlier of Folly Lake mafic rocks are most commonly light pink colored. They have variable graphic or glomeroporphyritic textures with phenocrysts of quartz and perthite (orthoclase and albite) in an allotriomorphic groundmass (Table 1 and Plate 1D). Opaques (ilmenite, rutile, hematite and magnetite) occur in dispersed anhedral crystal aggregates. Pleochroic green hornblende is rare; ragged biotite and/or chlorite is found in polycrystalline masses, probably as secondary alteration of the amphiboles. Accessory minerals are zircon, sphene, rare fluorite, and, in one sample, zoned yellow brown tourmaline.

\section{GEOCHEMISTRY: DATA AND INTERPRETATION}

A total of 21 samples from the Pleasant Hills and Hart Lake - Byers Lake plutons have been analyzed for 10 major and minor elements and 14 trace elements (Table 2). These comprise a representative suite of samples from the fine-grained granite of the Pleasant Hills pluton, and a small number of samples from the principal rock types of the Hart Lake - Byers Lake pluton. Analysis of further samples is in progress. Because the analyses for the fine-grained phase of the Pleasant Hills pluton are the most complete, the discussion is largely based on this data set.
The major element abundances indicate that the Pleasant Hills and Hart Lake - Byers Lake plutons are alkali granites. When compared with well-known peraluminous granites (such as the South Mountain Batholith: McKenzie and Clarke, 1975) or island arc granites (such as reviewed by Pearce et al., 1984) they have relatively low amounts of $\mathrm{Al}_{2} \mathrm{O}_{3}$ and $\mathrm{CaO}$ and high total alkalies. Normative Q $z^{\prime}$ and An' are high, so that the granites classify as alkali feldspar granite in the chemical scheme of Streckeisen and Lemaitre (1979). The high molar ratio of $\left(\mathrm{Na}_{2} \mathrm{O}+\mathrm{K}_{2} \mathrm{O}\right)$ to $\mathrm{Al}_{2} \mathrm{O}_{3}$ (Table 2) also indicates their alkaline character (Hermes et al., 1978). Many of the rocks contain very small amount of corundum (0-1.6\% - average $0.5 \%)$ in the CIPW norms, distinguishing them from peraluminous granites. When compared with alkali granites (such as the Paleozoic alkali granites from the Avalon zone of New England described by Hermes et al., 1978), the Hart Lake - Byers Lake pluton is generally comparable whereas some of the Pleasant Hills granites fall in their field of subalkalic granites (Fig. 3).

The geochemical data available indicate that in the finegrained phase of the Pleasant Hills pluton, granites from the West Economy River (open circles in Fig. 4) have a lower $\mathrm{SiO}_{2}$ content than those from Chain Lake Brook (solid circles in Fig. 4). As $\mathrm{SiO}_{2}$ increases, there is a decrease of $\mathrm{Al}_{2} \mathrm{O}_{3}, \mathrm{TiO}_{2}, \mathrm{Fe}_{2} \mathrm{O}_{3 \mathrm{e}}, \mathrm{Na}_{2} \mathrm{O}$, $\mathrm{CaO}, \mathrm{MnO}, \mathrm{Ba}, \mathrm{Zr}$; constant $\mathrm{MgO}$; slight increase in $\mathrm{P}_{2} \mathrm{O}_{5}$ and $\mathrm{Sr}$; and clear increase of $\mathrm{K}_{2} \mathrm{O}$ and $\mathrm{Rb}$ (Fig. 4).

The probable fractionation trends in the Pleasant Hills granite is inferred from plots of trace elements shown in Figure 5. These indicate that there was fractionation of K-feldspar ( $\mathrm{Ba} v$. $\mathrm{Sr}$ and $\mathrm{Ba} \mathrm{v} . \mathrm{Rb}$ ) and fractionation of biotite (Ba v. Sr). A plot of $\mathrm{Y}$ against $\mathrm{Zr}$ (Fig. 5) indicates an increase of $\mathrm{Y}$ with $\mathrm{Zr}$ for the less siliceous granite, whereas $\mathrm{Zr}$ remains constant (and lower) while $Y$ increases for the more siliceous granites. Zircon contains both $\mathrm{Zr}$ and $\mathrm{Y}$, whereas sphene contains $\mathrm{Y}$. The lower $\mathrm{Zr}$ in the more siliceous granites suggests that zircon saturation was attained resulting in zircon fractionation (Fig. 5); these granites have only minor zircon and sphene probably continued to contribute the higher amounts of $\mathrm{Y}$.

Thus, the overall trend seen in the Pleasant Hills granites could be due to fractionation controlled mainly by K-feldspar and probably also biotite. This trend may have been controlled also by the crystallization (saturation) of the accessory minerals, mainly zircon and sphene and probably apatite, although some of these trends may be inherited from partial melting of source rock.

Harker diagrams for the Hart Lake - Byers Lake pluton granites (Fig. 4) indicate that as $\mathrm{SiO}_{2}$ increases, there is a decrease in $\mathrm{Al}_{2} \mathrm{O}_{3}, \mathrm{~K}_{2} \mathrm{O}, \mathrm{Sr}, \mathrm{Ba}$ and probably $\mathrm{CaO}, \mathrm{Na}_{2} \mathrm{O}$ and $\mathrm{Rb}$; scatter for $\mathrm{Fe}_{2} \mathrm{O}_{31}, \mathrm{Zr}$ and $\mathrm{Y}$; and not much change for $\mathrm{TiO}_{2}, \mathrm{MnO}, \mathrm{P}_{2} \mathrm{O}_{5}$ and probably $\mathrm{MgO}$. Differentiation trend plots for these granites also indicate K-feldspar and biotite fractionation. Thus, the differentiation trends for the Hart Lake - Byers Lake pluton granites are most similar to the more siliceous granites of the Pleasant Hills pluton, and seem to continue the differentiation trend seen there to higher $\mathrm{SiO}_{2}$ values.

In major element composition, both the Pleasant Hills and the Hart Lake - Byers Lake granites are less aluminous and richer in Ti than typical collision granites (Harris et al., 1986), but are persistently richer in $\mathrm{K}_{2} \mathrm{O}$ than $\mathrm{Na}_{2} \mathrm{O}$, a feature typical of collision 


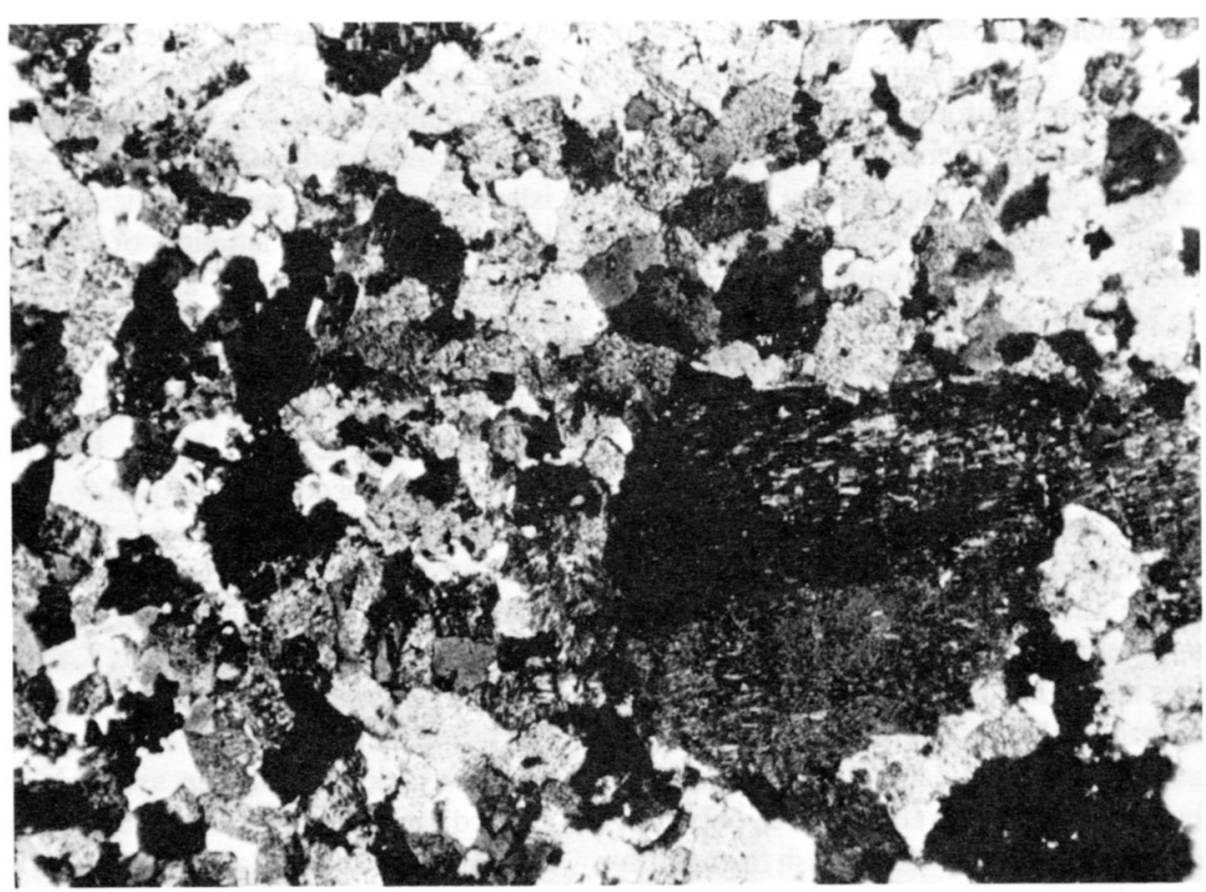

Plate 1A. Equigranular granite (West Economy River) of the Pleasant Hills pluton. Sample 26-13-6, crossed polars, field of view approximately 4.4 mm.

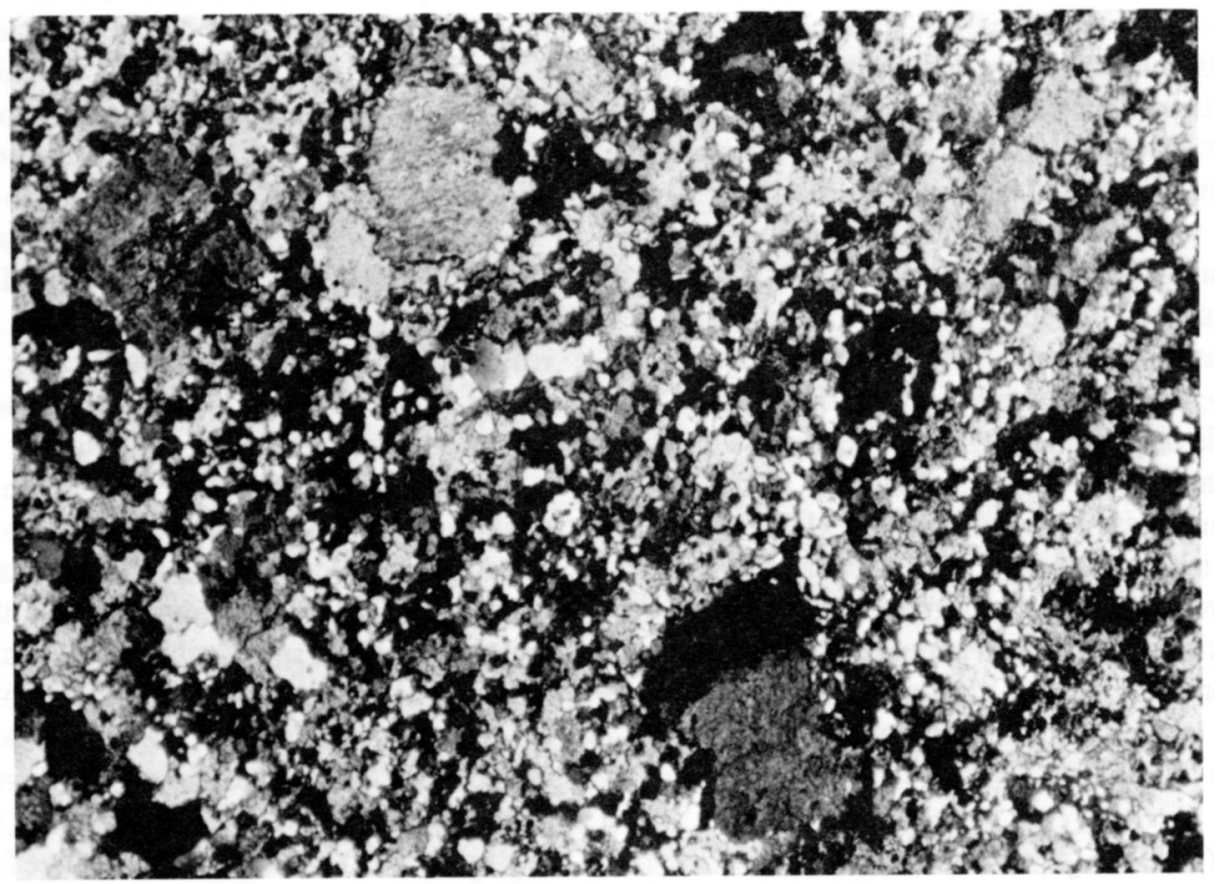

Plate 1B. Porphyritic granite (Chain Lake Brook) of the Pleasant Hills pluton. Sample 25-5-5, crossed polars, field of view approximately 4.4 mm.

granites. The trace element compositions of these granites are typical of within-plate granites (Fig. 6), consistently showing compositions of $\mathrm{Rb}, \mathrm{Nb}$, and $\mathrm{Y}$ similar to those described by Pearce et al. (1984). These granites do not show characteristics of post-collisional granites (Harris et al., 1986) such as depletion in $\mathrm{Nb}, \mathrm{Zr}, \mathrm{Y}, \mathrm{Ce}$ and $\mathrm{Hf}$.

\section{REGIONAL TECTONIC SIGNIFICANCE}

The Early Carboniferous granites of the eastern Cobequid Highlands are typical within-plate granites of alkaline character. They are similar to other Carboniferous plutons in the western Cobequid Highlands, which were intruded just north of the 


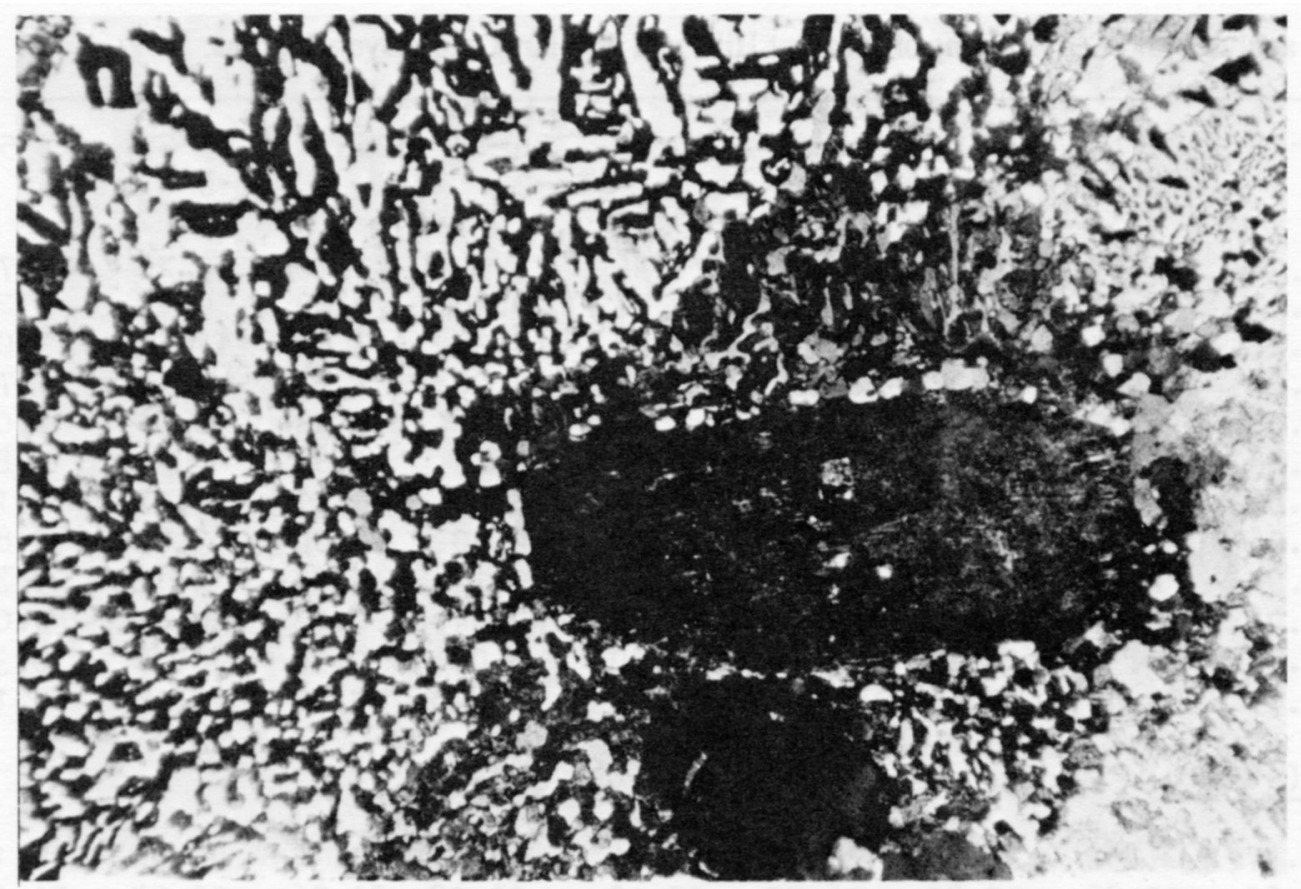

Plate 1C. Marginal granite with granophyric texture from the Hart Lake - Byers Lake pluton. Sample 36-6-1, crossed polars, field of view approximately $4.4 \mathrm{~mm}$.

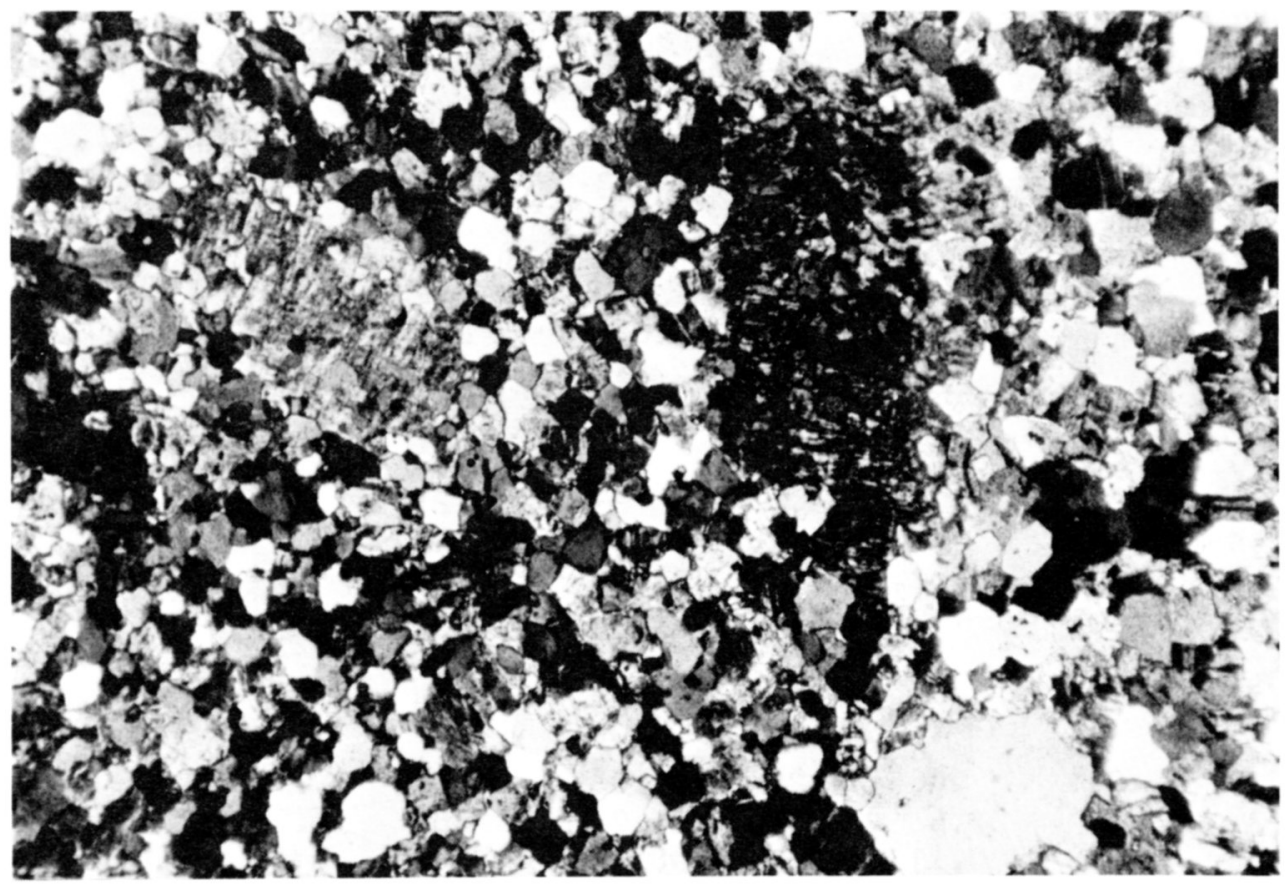

Plate 1D. Leucocratic granite from a dyke intruding mafic rocks within the Hart Lake - Byers Lake pluton. Sample 31-3-2, crossed polars, field of view approximately $4.4 \mathrm{~mm}$.

Cobequid Fault (Pe-Piper et al., submitted). The western Cobequid Highlands granites are slightly less alkaline. Only the Hart Lake - Byers Lake granite contains amphibole (including arfvedsonite); all the other plutons consist of two-feldspar biotite granite. The plutons in the western Cobequid Hills contain diorite stocks or pods, and common mafic dykes and sills. In contrast, in the eastern Cobequid Highlands, large gabbroic plutons are common, in which there appears to have been synchronous intrusion of mafic and felsic magmas.

The textures of the granites in the Pleasant Hills and Hart Lake - Byers Lake plutons, the occurrence of xenoliths of flow banded rhyolite, and the presence of porphyry stocks within the 
Table 2. Chemical analyses and CIPW norms of Pleasant Hills and the Hart Lake - Byers plutons.

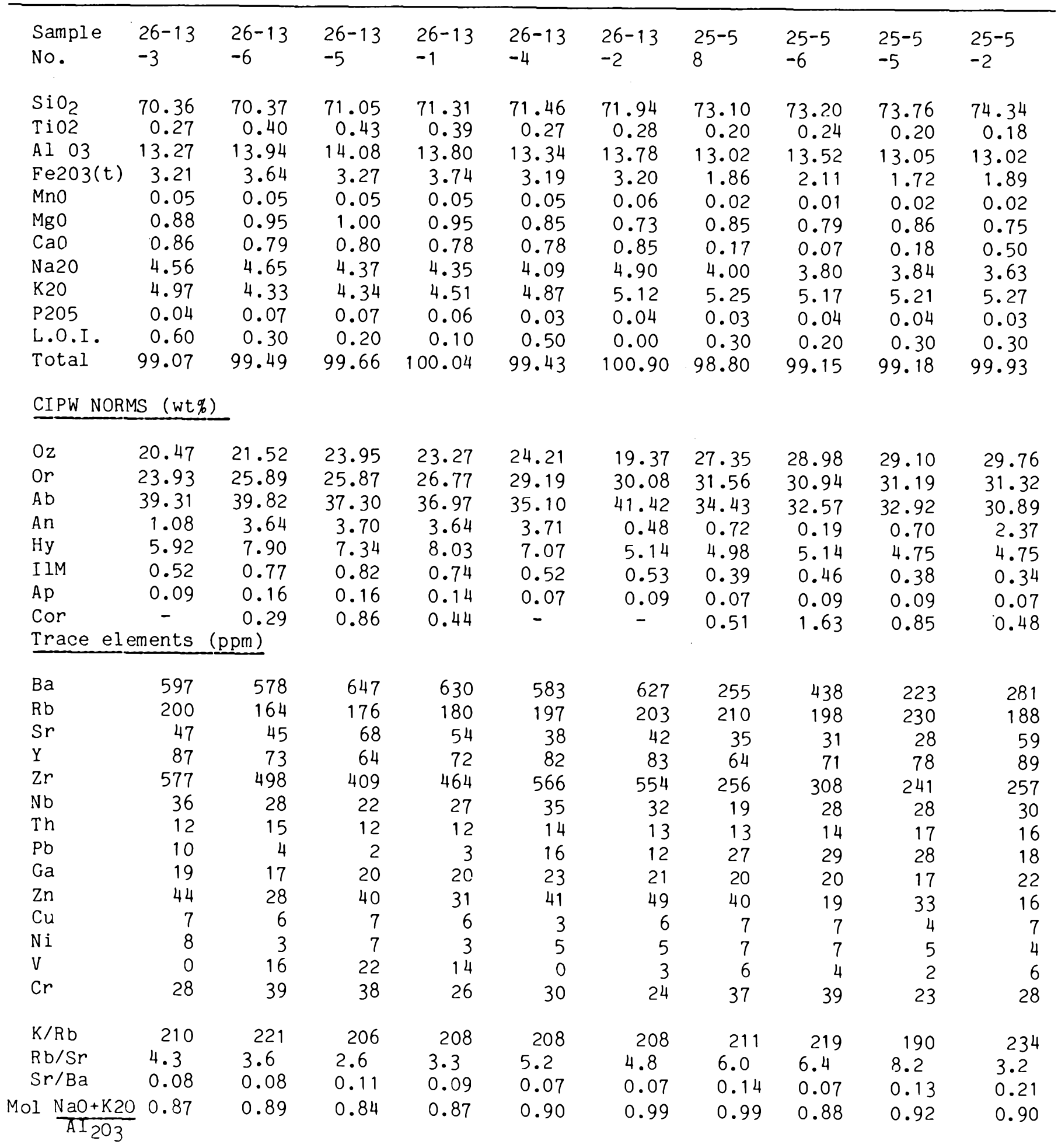


Table 2. Chemical analyses and CIPW norms of Pleasant Hills and the Hart Lake - Byers plutons.

Pleasant Hills

\begin{tabular}{lrrr} 
& \multicolumn{1}{l}{4} & \multicolumn{1}{l}{1} & \multicolumn{1}{l}{} \\
Si02 & 74.73 & 75.21 & 75.52 \\
Ti02 & 0.20 & 0.17 & 0.20 \\
Al203 & 13.13 & 12.62 & 13.16 \\
Fe203t & 1.82 & 1.76 & 1.68 \\
MnO & 0.02 & 0.02 & 0.02 \\
MgO & 0.78 & 0.90 & 0.78 \\
CaO & 0.22 & 0.27 & 0.28 \\
Na20 & 3.60 & 3.49 & 3.44 \\
K2O & 5.30 & 5.13 & 5.44 \\
P205 & 0.03 & 0.02 & 0.03 \\
L.O.I. & 0.00 & 0.20 & 0.10 \\
Total & 99.83 & 99.79 & 100.65
\end{tabular}

CIPW Norms (\%)

Qz $\quad 30.79$

or $\quad 31.43$

$\mathrm{Ab} \quad 30.57$

An $\quad 0.95$

Hy $\quad 4.67$

$\begin{array}{ll}\text { Di } & - \\ \text { Ilm } & 0.38\end{array}$

Ap $\quad 0.07$

Cor
32.35

30.50

29.71

1.26

4.93

0.32

0.05

0.87
31.72

32.03

29.00

1.24

4.41

$-$

0.38

0.07

1.15
25-53.

75.69

0.18

12.62

1.53

0.03

0.79

0.61

3.62

4.85

0.03

0.00

99.95
25-5$1 \mathrm{~A}$

76.33

0.18

12.88

1.81

0.02

0.84

0.23

3.50

5.02

0.02

0.00

100.83
$36-2-$
1

$$
72.90
$$

0.22

13.76

1.85

0.03

0.89

0.44

4.00

5.55

0.03

0.40

100.07
Hart Lake-Byers Lake

35-5-

$3^{36-7-}$

$l^{36-5-}$

35-7-

29-8-

5

$\begin{array}{rr}73.35 & 73.83 \\ 0.23 & 0.23\end{array}$

74.76

74.94

75.79

$13.10 \quad 13.13$

$2.14 \quad 2.04$

0.04

0.03

0.15

0.20

0.17

$11.79 \quad 11.86$

1.85

2.79

0.03

0.05

12.09

0.82

0.46

1.06

0.43

4.10

0.73

0.16

0.83

0.30

3.91

5.11

0.03

4.79

0.05

0.10

0.30

4.88

0.03

0.30

3.44

4.77

0.03

0.20

99.41

1.68

0.04

0.77

0.43

3.92

4.56

0.03

0.10

99.58

Trace el ements (ppm)

\begin{tabular}{|c|c|c|c|c|c|c|c|c|c|c|c|}
\hline $\mathrm{Ba}$ & 215 & 196 & 192 & 325 & 186 & 285 & 206 & 179 & 44 & 55 & 103 \\
\hline $\mathrm{Rb}$ & 204 & 211 & 236 & 178 & 205 & 240 & 254 & 220 & 205 & 237 & 127 \\
\hline $\mathrm{Sr}$ & 30 & 23 & 24 & 69 & 21 & 37 & 35 & 33 & 3 & 15 & 25 \\
\hline Y & 75 & 83 & 81 & 64 & 92 & 60 & 85 & 116 & 96 & 114 & 70 \\
\hline $\mathrm{Zr}$ & 247 & 247 & 245 & 242 & 237 & 212 & 292 & 308 & 306 & 548 & 142 \\
\hline $\mathrm{Nb}$ & 30 & 32 & 30 & 29 & 31 & 23 & 54 & 55 & 62 & 81 & 37 \\
\hline Th & 17 & 20 & 16 & 14 & 21 & 22 & 20 & 24 & 15 & 17 & 13 \\
\hline $\mathrm{Pb}$ & 28 & 12 & 17 & 9 & 11 & 17 & 25 & 15 & 8 & 21 & 7 \\
\hline $\mathrm{Ga}$ & 19 & 21 & 22 & 18 & 19 & 20 & 25 & 22 & 23 & 30 & 21 \\
\hline $\mathrm{Zn}$ & 33 & 38 & 30 & 17 & 35 & 32 & 58 & 27 & 43 & 161 & 46 \\
\hline $\mathrm{Cu}$ & 6 & 5 & 4 & 0 & 8 & 0 & 6 & 2 & 4 & 4 & 4 \\
\hline $\mathrm{Ni}$ & 8 & 4 & 8 & 6 & 5 & 5 & 7 & 7 & 5 & 6 & 5 \\
\hline v & 0 & 0 & 3 & 0 & 1 & 21 & 4 & 4 & 0 & 2 & 0 \\
\hline $\mathrm{Cr}$ & 41 & 18 & 22 & 32 & 23 & 21 & 32 & 31 & 38 & 31 & 59 \\
\hline $\mathrm{K} / \mathrm{Rb}$ & 216 & 203 & 190 & 226 & 202 & 193 & 168 & 181 & 201 & 168 & 300 \\
\hline $\mathrm{Rb} / \mathrm{Sr}$ & 6.8 & 9.2 & 9.8 & 2.6 & 9.8 & 6.5 & 7.3 & 6.7 & 68.3 & 15.8 & 5.1 \\
\hline $\mathrm{Sr} / \mathrm{Ba}$ & 0.14 & 0.12 & 0.13 & 0.21 & 0.11 & 0.13 & 0.17 & 0.18 & 0.07 & 0.27 & 0.24 \\
\hline $\mathrm{Na}_{2} \mathrm{O}=\mathrm{K}_{2}$ & 0.89 & 0.89 & 0.88 & 0.89 & 0.86 & 0.91 & 0.96 & 0.91 & 0.99 & 0.91 & 0.94 \\
\hline
\end{tabular}

32.64

28.72

30.69

2.93

4.26

0.34

0.07

0.35
33.57

29.48

29.43

1.05

4.79

0.34

0.05

1.29
25.04
32.97
34.02
2.07
4.99
-
0.42
0.07
0.42

25.53
30.39

36.54

1.41

4.99

0.63

0.44

0.07

$-$

$-$
28.00

28.45

34.87

1.87

5.71

0.44

0.12

0.52
31.35

29.40

33.73

0.21

4.60

0.34

0.29

0.07

$-$
33.20

28.49

29.42

1.32

6.51

0.38

0.07

0.56
32.59

27.14

33.40

1.94

4.49

0.03

0.33

0.07
$-$ 
Note to Table 2:

Analytical procedures. Analyses were made on a Phillips PW1400 sequential X-ray fluorescence spectrometer using a Rh-anode X-ray tube at St. Mary's University. Major oxide determinations were carried out on fused glass discs, while trace elements were done on pressed powder pellets. International standards with recommended values from Abbey (1983) as well as in-house standards were used for calibration. Analytical precision, as determined on replicate analyses, is generally better that $2 \%$ for most elements. Loss on ignition (LOI) was determined by heating the sample for 1.5 hours at $1050^{\circ} \mathrm{C}$ in an electric furnace.

Description of analysed samples. 36-2-1: Fine-grained marginal granite with granitic texture, containing alkali feldspar, plagioclase, quartz, chlorite, opaques, calcite and zircon. 35-5-1: Fine-grained marginal granite with slightly porphyritic texture having microphenocrysts of perthite and graphic groundmass of perthite, quartz, homblende, chlorite, opaques, zircon, biotite and allanite. 36-7-1: Coarse-grained granite with graphic texture containing perthite, quartz, minor discrete plagioclase grains, chlorite after biotite, homblende, allanite, opaques, zircon and epidote. 36-5-1: Medium-grained granite with graphic texture containing perthite, quartz, opaques, sphene, zircon, chlorite and fluorite. 35-7-1: Coarse-grained granite with graphic texture, containing perthite, quartz, few discrete albite laths, riebeckite, homblende, zircon, sphene, opaques, allanite and fluorite. 29-8-5: Coarsegrained granite with crude graphic texture containing perthite, quartz, minor plagioclase and microcline crystals, hornblende, allanite, opaques and zircon. 26-13-3: Porphyritic granite with phenocrysts of orthoclase and plagioclase and micromyrmekitic groundmass of feldspar, quartz, biotite, chlorite, opaques, zircon, sphene, fluorite and epidote. 26-13-6, 26-13-1, 26-13-4, 26-13-2: Slightly porphyritic granite with microphenocrysts of perthite and granitic groundmass containing perthite, quartz, biotite, opaques, zircon, sphene, rutile and fluorite. 25-5-8, 25-5-6, 25-5-5: Porphyritic granite with phenocrysts of perthite, quartz and plagioclase in myrmeketic-like groundmass of quartz, perthite, zircon, biotite, opaques, muscovite, apatite and sphene. 25-5-2, 25-5-4, 25-5-1, 25-5-7, 25-5-3, 25-5-1 A: Porphyritic granite with phenocrysts of perthite in a micrographic texture of feldspar, quartz, opaques, muscóvite, biotite, zircon and epidote.

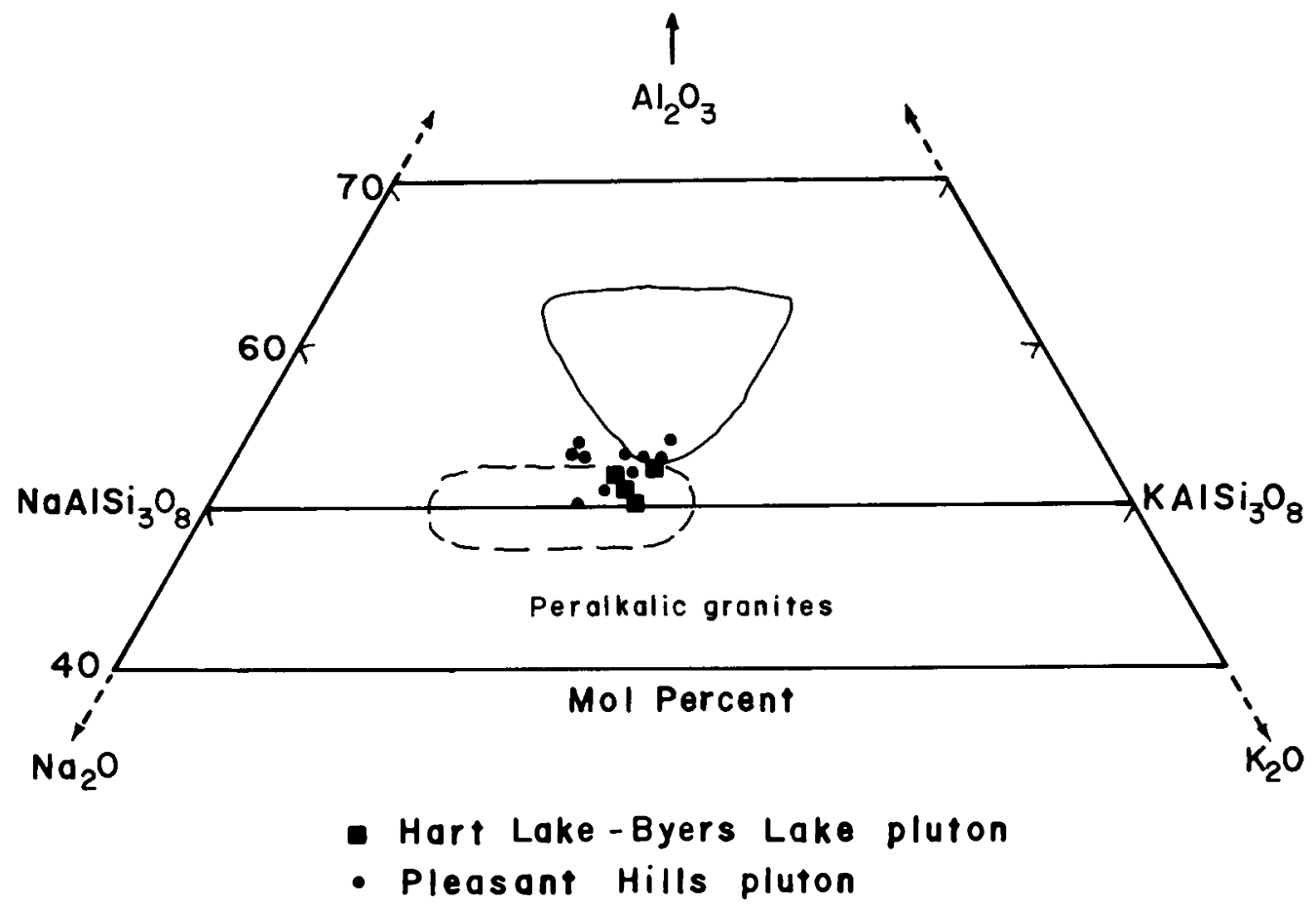

Fig. 3. Molecular proportion of $\mathrm{Na}_{2} \mathrm{O}, \mathrm{K}_{2} \mathrm{O}$ and $\mathrm{Al}_{2} \mathrm{O}_{3}$ for the Carboniferous granites of the eastern Cobequid Highlands compared with alkali (dashedline field) and sub-alkali granites (solid-line field) from New England (after Hermes et al., 1978). Note because some analyses are very similar, in this and subsequent figures, for clarity not all analyses have been plotted.

Pleasant Hills pluton all suggest that the granites formed at a high structural level, probably in part intruding their own extrusive counterparts of the Fountain Lake Group.

The abundance of Devono-Carboniferous plutonism in the Cobequid Highlands compared with elsewhere in the Avalon Terrane suggests a local structural control. The bimodal nature of the magmatism and the alkalic within-plate magmatic affinity indicate emplacement in a local extensional tectonic environment. This extension may be associated with the regional dextral shear. A similar model for the emplacement of granite in a zone of local extensional along a shear zone has recently been proposed by Guinberteau et al. (1987) for granite of similar age in western France. In the Meguma Terrane Dallmeyer and Keppie (1987) document that the ca. 375-315 Ma emplacement of granitic stocks was associated with dextral shear. More work is required to document precisely the timing of the magmatism and its relationship to fault movement, and the role played by the major mafic magma bodies in the petrogenesis of the plutons.

\section{ACKNOWLEDGEMENTS}

This work was supported by the Geological Survey of Canada through the Nova Scotia - Canada Mineral Development Agreement and by NSERC grants to G. Pe-Piper and J.B. 

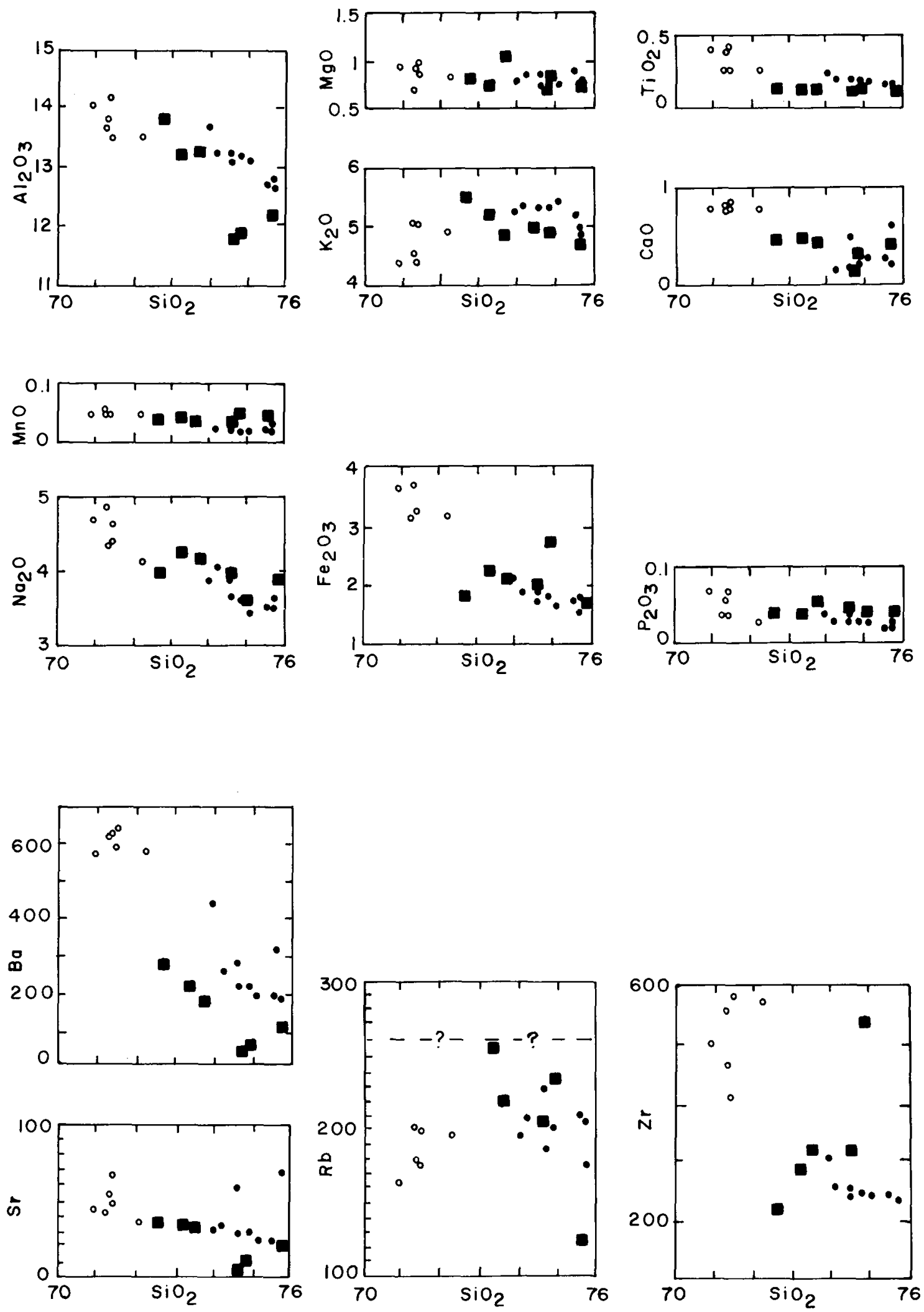

Fig. 4. Major and trace element variations with $\mathrm{SiO}_{2}$ for the Pleasant Hills and Hart Lake - Byers Lake granites. Pleasant Hills: open circles from West Economy River (e in Fig. 2); solid circles from Chain Lake Brook (d in Fig. 2); squares from Hart Lake - Byers Lake granite. 

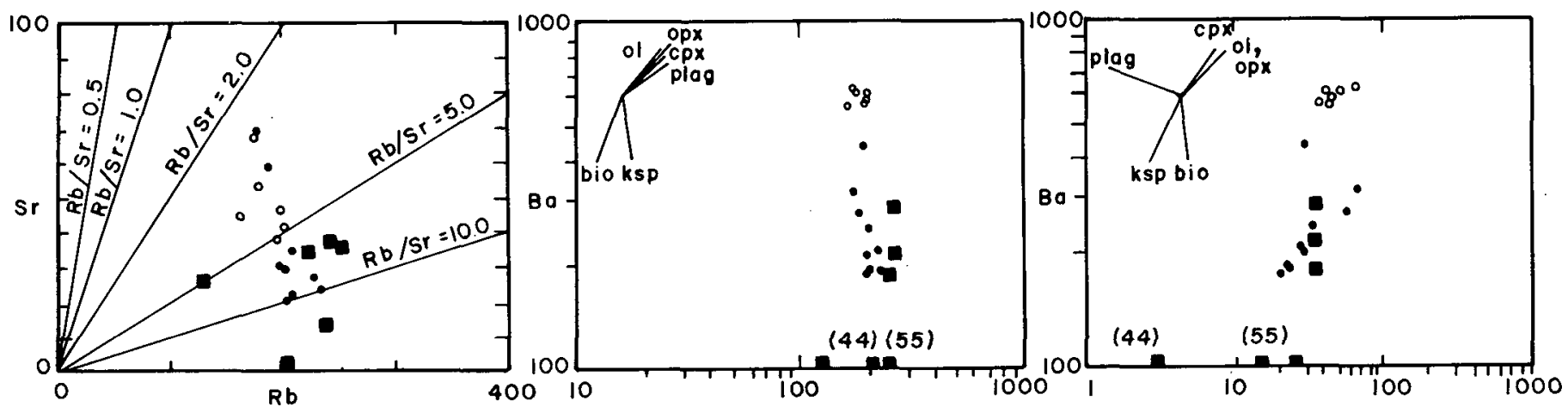

Fig. 5. Sr v. Rb, Ba v. Rb, Ba v. Sr and Y v. Zr for the Pleasant Hills and Hart Lake - Byers Lake granites. The mineral vectors are taken from Tindle and Pearce (1981). Symbols as in Figure 4.

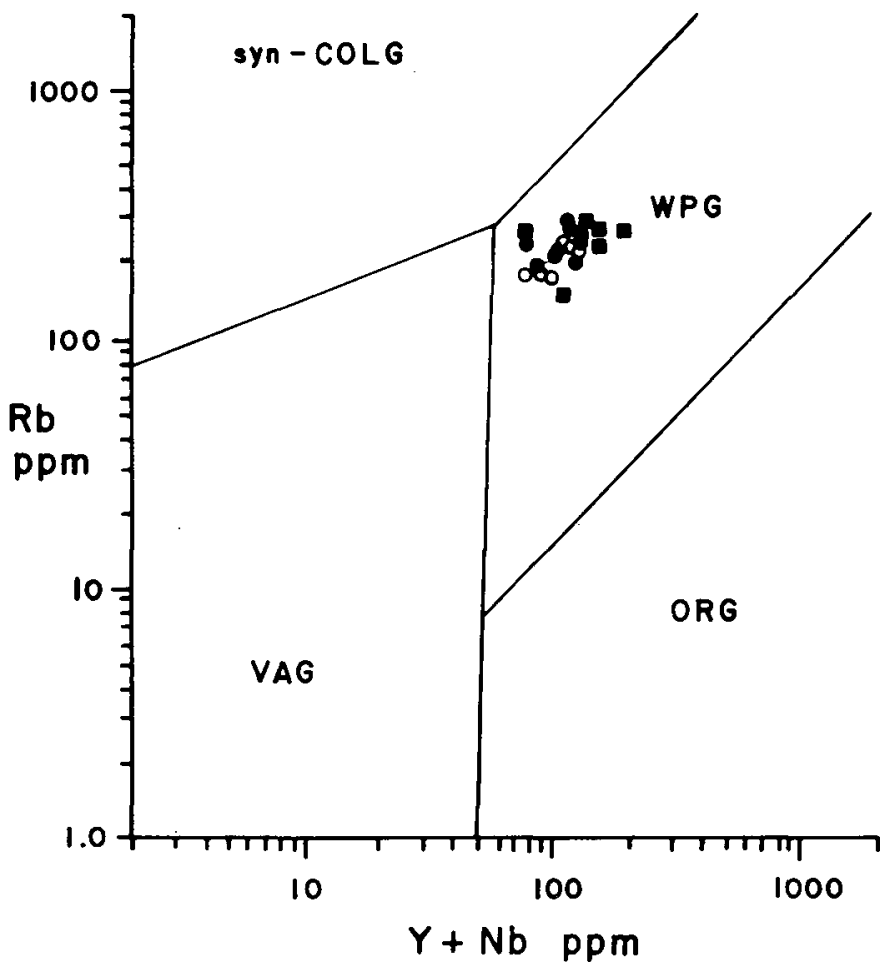

Fig. 6. Plot of $\mathrm{Rb}$ against $\mathrm{Y}+\mathrm{Nb}$ for Pleasant Hills and Hart Lake - Byers Lake pluton granites. Symbols as in Figure 4. Discrimination fields after Pearce et al. (1984). ORG - ocean ridge granites, WPG - within plate granites, VAG - volcanic arc granites, Syn-COLG - syn-collision granites.

Murphy. The geochemical work was done at the Saint Mary's University regional X-ray fluorescence centre and the Dalhousie University regional electron microprobe centre. Reviews by D.J.W. Piper and two anonymous journal referees substantially improved this paper.

ABBEY, S. 1983. Studies in "Standard Samples" of Silicate Rocks and Minerals, 1969-1982. Geological Survey of Canada, Paper 83-15, $114 \mathrm{p}$.

CORMIER, R.F. 1979. Rubidium/Strontium isochron ages of Nova Scotia granitoid plutons. Nova Scotia Department of Mines, Report 79-1, pp. 143-148.

DALLMEYER, R.D. and KEPPIE, J.D. 1987. Polyphase late Paleozoic tectonothermal evolution of the southwestern Meguma terrane,
Nova Scotia: evidence from ${ }^{40} \mathrm{Ar} /{ }^{9} \mathrm{Ar}$ mineral ages. Canadian Journal of Earth Sciences, 24, pp. 1242-1254.

DONOHOE, H.V., HALLIDAY, A.N., and KEPPIE, J.D. 1986. Two $\mathrm{Rb}-\mathrm{Sr}$ whole rock isochrons from plutons in the Cobequid Highlands, Nova Scotia, Canada. Maritime Sediments and Atlantic Geology, 22, pp. 148-154.

DONOHOE, H.V. and WALLACE, P.I. 1982. Geological map of the Cobequid Highlands, Nova Scotia. Scale 1:50 000. Nova Scotia Department of Mines and Energy.

DONOHOE, H.V. and WALLACE, P.I. 1985. Repeated orogeny, faulting and stratigraphy in the Cobequid Highlands, Avalon Terrain of Nova Scotia. Excursion 3, Geological Association of Canada - Mineralogical Association of Canada, Joint Annual Meeting, Fredericton, New Brunswick, 77 p.

DONOHOE, H.V. and WALLACE, P.I. 1988. Movement history of the Cobequid Fault Zone, Cobequid Highlands, northem Nova Scotia. Abstracts, Atlantic Geoscience Society, Colloquium '88, Antigonish, Nova Scotia, p. 26.

GUINEBERTEAU, B., BOUCHEZ, J-L., and VIGNERESSE, J-1. 1987. The Mortagne granite pluton (France) emplaced by pull-apart along a shear zone: Structural and gravimetric arguments and regional implication. Geological Society of America Bulletin, 99, pp. 763-770.

HARRIS, N.B.W., PEARCE, J.A., and TINDLE, A.G. 1986. Geochemical characteristics of collision zone magmatism. In Collision tectonics. Edited by R.M. Shackleton, A.C. Ries, and M.P. Coward. Geological Society of London, Special Publication 19, pp. 67 81.

HERMES, O.D., BALLARD, R.D., and BANKS, P.O. 1978. Upper Ordovician peralkalic granites from the Gulf of Maine. Geological Society of America Bulletin, 89, pp. 1761-1774.

KEPPIE, J.D. and DALLMEYER, R.D. 1987. Dating transcurrent terrane accretion: an example from the Meguma and Avalon composite terranes in the northem Appalachian Orogen. Tectonics, 6, pp. 831-847.

MCKENZIE, C. and CLARKE, D.B. 1975. Petrology of the South Mountain Batholith, Nova Scotia. Canadian Journal of Earth Sciences, 12, pp. 1209-1218.

PEARCE, J.A., HARRIS, N.B.W., and TINDLE, A.G. 1984. Trace element discrimination diagrams for tectonic interpretation of granitic rocks. Journal of Petrology, 25, pp. 952-983.

PE-PIPER, G., CORMIER, R.F., and PIPER, D.J.W. Submitted. The age and significance of Carboniferous plutons of the Westem Cobequid Hills, Nova Scotia. Canadian Journal of Earth Sciences.

RYAN, R.J., CALDER, J.H., DONOHOE, H.V., Jr., and NAYLOR, R. 1987. Late Paleozoic sedimentation and basin development adja- 
cent to the Cobequid Highlands Massif, Eastem Canada. Canadian Society of Petroleum Geologists, Memoir 12, pp. 311-317.

STRECKEISEN, A. and LEMAITRE, R.W. 1979. A chemical approximation to the modal QAPF classification of igneous rocks. Neues Jahrbuch für Mineralogie, Abhandlungen, 136, pp. 169-206.
TINDLE, A.G. and PEARCE, J.A. 1981. Petrogenetic modelling of in situ fractional crystallization in the zoned Loch Doon pluton, Scotland. Contributions to Mineralogy and Petrology, 78, pp. 196207. 